\title{
CORD FORMATION AND COLONY MORPHOLOGY FOR THE PRESUMPTIVE IDENTIFICATION OF MYCOBACTERIUM TUBERCULOSIS COMPLEX
}

\author{
Paulo Henrique Tasso Monteiro; Maria Conceição Martins*; Suely Yoko Mizuka Ueki; \\ Carmen Maria Saraiva Giampaglia; Maria Alice da Silva Telles \\ Instituto Adolfo Lutz, São Paulo, SP, Brasil
}

Submitted: February 26, 2002; Returned to authors for corrections: January 14, 2003; Approved: May 08, 2003

\begin{abstract}
The identification of Mycobacterium tuberculosis complex (MT), using non-molecular methods, is timeconsuming. The objective of this study was to evaluate a screening test for the presumptive identification of MT, which could potentially decrease laboratory turn-around time for reporting preliminary results. From January 1998 to December 1999, 3056 cultures were analysed at the Mycobacterial Laboratory, Instituto Adolfo Lutz, São Paulo, Brasil. The screening test consisted of observation of colony morphology on Löwenstein Jensen medium and evaluation of cord formation on smear microscopy from those positive cultures. After the screening test, the cultures identified as non-tuberculous mycobacteria were identified to species by conventional methods (growth on culture and biochemical tests). Those identified as MT were submitted to drug susceptibility tests. The presumptive identification of MT using the proposed screening test, when compared with conventional tests, presented $98.9,86.9,97.8$ and $93.0 \%$ of sensitivity, specificity, positive and negative predictive values, respectively. The conclusion is that it is possible to make a presumptive identification of MT using visual analysis of colony morphology and cord formation on microscopy examination. This method could be used to report the presumptive identification of MT and to guide laboratory decisions regarding susceptibility and identification tests with little cost and in a very practical way.
\end{abstract}

Key words: Mycobacterium tuberculosis, identification, cord formation, culture

\section{INTRODUCTION}

Mycobacterium tuberculosis, the agent of human tuberculosis, has been estimated to have infected $1 / 3$ of the world population, with 3 million deaths per year. The delay in making the correct diagnosis and the identification of species are the major difficulties that increase the problem of this disease. The laboratory team has to decide which mycobacteria isolated are Mycobacterium tuberculosis complex (MT) and which are non-tuberculous mycobacteria (NTM).

Some studies have evaluated the utility of cord formation in liquid or solid medium for the presumptive identification of MT and to guide decisions regarding susceptibility tests or species identification $(1,3,6,8,9)$.
The distinctive colony morphology of mycobacteria when grown on solid medium also helps to characterize the species (5).

The objective of this study was to evaluate a screening test that consists of visual analysis of colony morphology on solid media and the presence of cording on microscopy for presumptive identification of MT.

\section{MATERIALS AND METHODS}

From January 1998 to December 1999, 3056 cultures were analysed at the Mycobacterial Laboratory of Institute Adolfo Lutz (IAL), São Paulo, Brasil.

Smears from the positive cultures were prepared according to Collins et al. (3). Briefly, a small amount of growth from the

\footnotetext{
* Corresponding author: Instituto Adolfo Lutz, Seção de Bacteriologia. Av. Dr. Arnaldo, 351 - $9^{\circ}$ andar. 01246-900, São Paulo, SP, Brasil. Fax: (+5511) 3085-3505. E-mail: mcmartin@ial.sp.gov.br
} 
culture was gently rubbed, not disturbing the bacilli arrangement, in a drop of saturated solution of mercury chloride on a microscope slide. This chemical solution quickly kills all mycobacteria thus eliminating the risk of infection for the laboratory workers. After drying, the smears were heat- fixed and stained by Ziehl-Neelsen method.

The microscopic appearance was evaluated for cording. Smears with only a few organisms on the slide were considered doubtful and not included in the study. Serpentine cording was defined as tight rope-like aggregates of acid-fast bacilli in which the long axis of the bacteria parallel the long axis of the cord. The uniform distribution or other arrangement was considered absence of cording $(3,6)$

The presence of cording was presumed to be of MT colonies while its absence was of NTM colonies (Fig. 1). The colony morphology was evaluated by analyzing the mycobacterial growth on Löwenstein Jensen medium. Cultures showing the typical cream coloured buff rough colonies were considered as possibly MT, while those showing smooth, humid, yellow, orange or cream-coloured colonies were considered NTM.

After being screened those cultures suspected of being NTM were identified through standardized methods of International Reference Centers, which included biochemical tests and growth on specific media and for those identified as MT, drug susceptibility tests were performed $(3,5,7)$.

\section{RESULTS}

The prevalence of MT among mycobacteria identified at Institute Adolfo Lutz in 1998-1999 was $85.5 \%$ and therefore the presumptive identification of these species was an important issue. Out of 3056 cultures evaluated, 64 (2.09\%) had a doubtful result for cording and were excluded of the study. Of remaining 2992 cultures, $2226(74.4 \%)$ were presumptively identified as MT and after conventional identification 2160 (97.0\%) were confirmed as MT. The NTM cultures were 24 complexo $M$. avium, 21 M. kansasii, 03 M. szulgai, 10 M. chelonae, 05 M. fortuitum and 03 M. phlei. Of $766(25.6 \%)$ cultures without cord formation, $441(57.6 \%)$ were later identified as MT and 325 (42.4\%) as NTM.
The presumptive identification of MT based on cord formation alone had sensitivity, specificity, positive and negative predictive values of $83.0,83.1,97.0$ and $42.4 \%$, respectively.

When colony morphology was added to microscopy for the screening of cultures for MT, the accuracy improved. The results of screening test were compared with conventional ones to validate that presumptive identification (Table 1).

Both cord formation and culture morphology were important for the presumptive identification of MT, but when results disagreed, the more consistent ones were chosen. For example, when cording was observed but the cultures were yelow to orange coloured or smooth, the culture morphology prevailed. When cording was negative, the cream coloured buff rough colonies were considered. In case of disgonic, dried or humid cultures, the cord formation was considered more important.

The presumptive identification of MT using both criteria had sensitivity, specificity, positive and negative predictive value of $98.9,86.9,97.8$ and $93.0 \%$ respectively.

Table 1. Screening test for presumptive identification of Mycobacterium tuberculosis. Instituto Adolfo Lutz, São Paulo, 1998-1999.

\begin{tabular}{|c|c|c|c|c|c|c|}
\hline \multirow{3}{*}{$\begin{array}{l}\text { Presumptive } \\
\text { identification }\end{array}$} & \multirow{2}{*}{\multicolumn{2}{|c|}{ Cultures }} & \multicolumn{4}{|c|}{ Conventional identification } \\
\hline & & & \multicolumn{2}{|c|}{$\begin{array}{c}\text { Mycobacterium } \\
\text { tuberculosis } \\
\text { (MT) }\end{array}$} & \multicolumn{2}{|c|}{$\begin{array}{c}\text { Non tuberculous } \\
\text { mycobacteria } \\
\text { (NTM) }\end{array}$} \\
\hline & $\mathrm{N}^{\mathrm{o}}$ & $\%$ & $\mathrm{~N}^{\mathrm{o}}$ & $\%$ & $\mathrm{~N}^{\mathrm{o}}$ & $\%$ \\
\hline \multicolumn{7}{|l|}{ Cord formation } \\
\hline Positive (MT) & 2,226 & 74.4 & 2,160 & 83.0 & 66 & 16.9 \\
\hline Negative (NTM) & 766 & 25.6 & 441 & 17.0 & 325 & 83.1 \\
\hline Total & 2,992 & 100.0 & 2,601 & 100.0 & 100.0 & 100.0 \\
\hline \multicolumn{7}{|l|}{ Screening test* } \\
\hline Positive (MT) & 2,585 & 86.4 & 2,528 & 98.9 & 57 & 13.1 \\
\hline Negative (NTM) & 407 & 13.6 & 29 & 1.1 & 378 & 86.9 \\
\hline Total & 2,992 & 100.0 & 2,557 & 100.0 & 435 & 100.0 \\
\hline
\end{tabular}

\section{DISCUSSION}

Reports about the utility of cord formation are usually based on mycobacterial growth in liquid medium. The sensitivity, specificity, and positive or negative predictive values were reported to be between 63.5 and $85.0 \%, 96.0$ and $99.6 \%, 90.0$ and $99.2 \%, 69.7$ and $98.8 \%$, respectively $(1,2,4,6,9)$. Although this study analyses mycobacterial cord 
formation in solid media, the sensitivity and positive predictive values agree with these reports but specificity and negative predictive values of 83.1 and $42.4 \%$ respectively, are lower. Morris et al (8) reported a sensitivity value of $23 \%$. Attorri et al (1), Mc Carter et al (6), and Yagupsky et al (9) reported improvements in the recognition of cord formation over time. Badak et al (2) observed that recognition of true cording can be difficult for inexperienced workers.

In this study, $17 \%$ of $M$. tuberculosis isolates exhibited no cord formation. This result is similar to the findings of other reports. However, loose, incomplete pseudocords produced by some NTM may have been misinterpreted as true cording $(2,6,9)$.

The majority of Brazilian laboratories use solid media to isolate mycobacteria and so it is possible to use both visual analysis of colony morphology and evaluation of cord formation by microscopy for the presumptive identification of MT.

This study detected a lower ratio (1.1\%) of disagreement of routine screening test (colony morphology and/or cording) when compared with the cording alone $(17.0 \%)$ for presumptive identification of MT as compared to the full identification method.

The validation of presumptive identification using the screening test compared with the conventional ones showed better sensitivity, specificity, positive and negative predictive values than those for cording alone.

The kappa statistic index, with a 95\% confidence interval, was a moderate value of $0.470(0.680-0.831)$ for cording alone and an almost perfect agreement value of 0.882 (0.757-0.972) for screening test. These indexes may be considered a measure of the relative efficacy of the test for presumptive identification of MT.

According to Kent and Kubica (5), the laboratory plays a pivotal role in the control of tuberculosis through the rapid detection, isolation and identification of mycobacterium species but the procedures are time-consuming, often taking weeks or even months to be completed. For this reason, preliminary reports should be issued. This evaluation of culture characteristics and presence of cording provides rapid preliminary information before the results of other identification tests are available.

The conclusion is that it is possible to make the presumptive identification of MT using visual analysis of colony morphology on solid media and the presence of cording on microscopy. This method could be used at regional laboratory to report a presumptive identification before sending the culture to a reference center for specific tests.

At central laboratory it could be very useful to guide decisions regarding susceptibility and identification tests with little cost and in a very practical way.

The final report should be provided after precise identification of the mycobacterial species on the basis of biochemical or molecular tests. The results of drug susceptibility tests could be informed only for isolates specifically identified as M. tuberculosis.

\section{ACKNOWLEDGMENTS}

The autors are grateful to Dr. Malcolm D. Yates, of the Mycobacterium Reference Unit, Dulwich Hospital, London, for reviewing the manuscript.

\section{RESUMO}

\section{Presença de corda e morfologia da colônia para a identificação presuntiva do complexo Mycobacterium tuberculosis}

O resultado da identificação convencional do complexo Mycobacterium tuberculosis (MT) é demorado. O objetivo deste estudo foi avaliar um teste de triagem para identificação presuntiva de MT e agilização da informação preliminar do resultado, baseado na análise da morfologia da colônia e da visualização de corda no exame microscópico do esfregaço feito da cultura. De janeiro de 1998 a dezembro de 1999 foram analisadas 3056 culturas no Instituto Adolfo Lutz, São Paulo, Brasil. As culturas classificadas como micobactérias não tuberculosas foram submetidas ao teste de identificação por método convencional (testes de crescimento em cultura e bioquímicos) e as MT foram submetidas ao teste de sensibilidade às drogas. Os resultados de sensibilidade, especificidade, valores preditivos positivo e negativo, obtidos com a comparação da identificação presuntiva de MT com o teste de triagem proposto e a identificação final com o método convencional, foram respectivamente 98,9, 86,9, 97,8 e 93,0\%. Concluiu-se que a análise da morfologia da colônia e da presença de corda no exame microscópico possibilitou a identificação presuntiva de MT. Este teste pode ser usado pelo laboratório para informação preliminar do resultado presuntivo e para direcionar de maneira prática e com baixo custo, os testes adicionais de sensibilidade às drogas ou de identificação de espécie que serão necessários.

Palavras-chave: Mycobacterium tuberculosis, identificação, corda e cultura

\section{REFERENCES}

1. Attorri, S.; Dunbar, S.; Clarridge II, J.E. Assesment of morphology for rapid presumptive identification of Mycobacterium tuberculosis and Mycobacterium kansasii. J. Clin. Microbiol., 38: 1.426-1.429, 2000.

2. Bardak, F.Z.; Goksel, S.; Sertoz, R.; Guzelant, A.; Kizirgil, A.; Bilgic, A. Cord formation in MB BacT medium is a reliable criterion for presumptive identification of Mycobacterium tuberculosis complex in laboratories with high prevalence of M. tuberculosis. J. Clin. Microbiol., 37: 4.189-4.191, 1999.

3. Collins, C.H.; Grange, J.M.; Yates, M.D. Tuberculosis Bacteriology: Organization and Practice. $2^{\text {nd }}$ ed. Butterworth Heinemann, London, 1997, 139p. 
4. Kaminski, D.A.; Hardy, D.J. Seletive utilization of DNA probes for identification of Mycobacterium species on the basis of cord formation in primary BACTEC 12B cultures. J. Clin. Microbiol., 28: 548-550, 1995.

5. Kent, P.T.; Kubica, G.P. Public Health Mycobacteriology. A guide for the level III laboratory. Centers for Disease Control, Atlanta Georgia, 1985, 207 pp.

6. Mc Carter, Y.; Ratkiewicz, I.N.; Robinson, A. Cord formation in BACTEC medium is a reliable, rapid method for presumptive identification of Mycobacterium tuberculosis complex. J. Clin. Microbiol., 36: 2.769-2.771, 1998.
7. Ministério da Saúde. Fundação Nacional da Saúde. Centro de Referência Professor Hélio Fraga. Manual de Bacteriologia da tuberculose. $2^{\text {a }}$. ed. Rio de Janeiro; 1994, 115p.

8. Morris, A.J.; Reller, L.B. Reliability of cord formation in BACTEC media for presumptive identification of mycobacteria. J. Clin. Microbiol., 31: 2.533-2.534, 1993.

9. Yagupsky, P.V.; Kaminski, D.A.; Palmer, K.M.; Nolte, F.S. Cord formation in BACTEC $7 \mathrm{H} 12$ medium for rapid, presumptive identification of Mycobacterium tuberculosis complex. J. Clin. Microbiol., 28: 1.451-1.453, 1990. 